\title{
APR 18.1956
}

PLEASE DO NOT DESTROY OR THROW AWAY THE PUBLICATHON. It you have ne further use for it, write to the Geolocical Survey at Washington and aki for a frank to retarn it

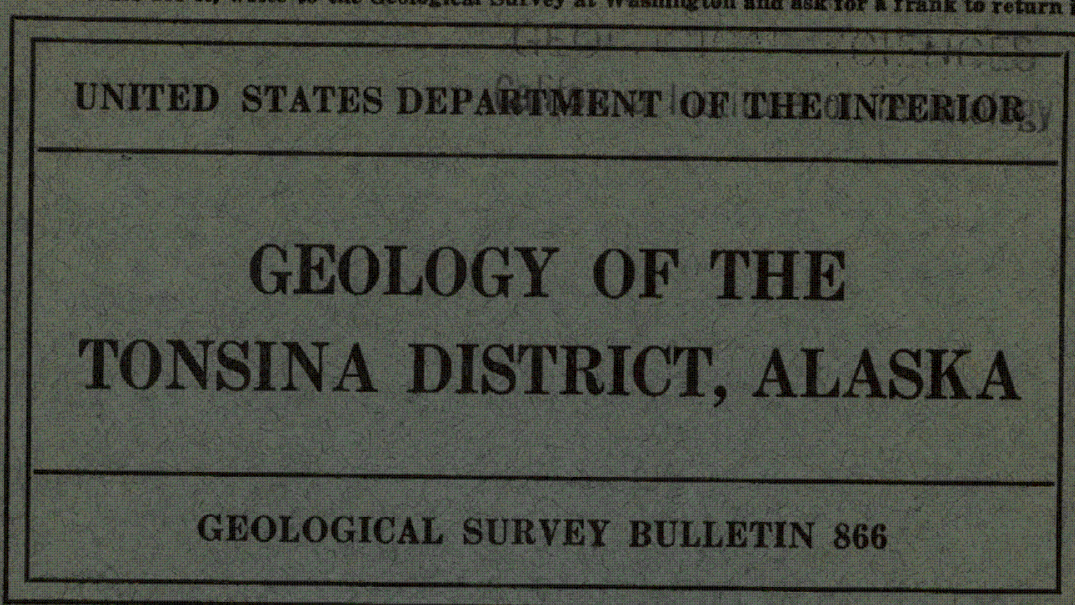

\section{GEOLOGICAL SURVEY BULLETIN 866}

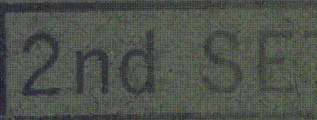





\section{UNITED STATES DEPARTMENT OF THE INTERIOR}

Harold L. Ickes, Secretary

GEOLOGICAL SURVEY

W. C. Mendenhall, Director

\section{Bulletin 866}

\section{GEOLOGY OF THE TONSINA DISTRICT, ALASKA}

BY

FRED H. MOFFIT

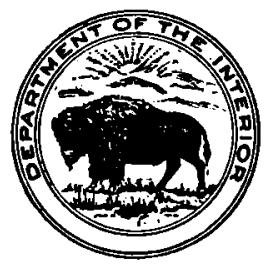

UNITED STATES

GOVERNMENT PRINTING OFFICE

WASHINGTON : 1935 


\section{CONTENTS}

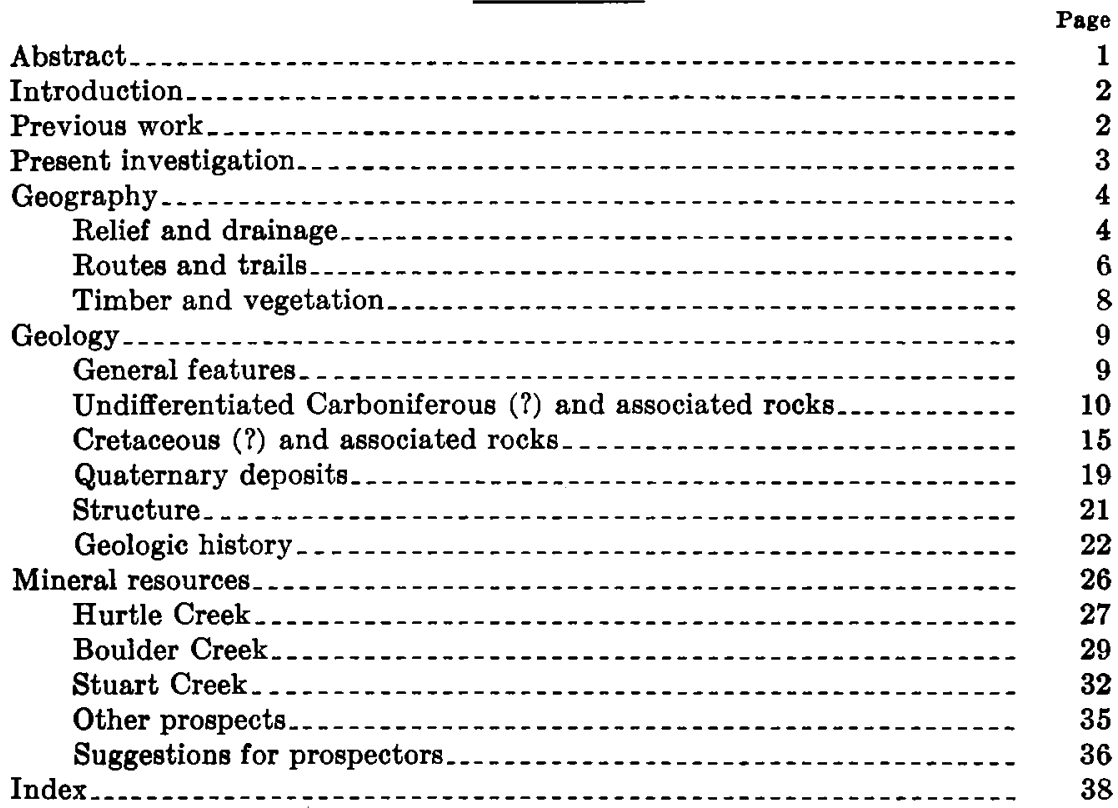

\section{ILLUSTRATIONS}

Plate 1. Geologic reconnaissance map of the Tonsina district, Alaska Figdre 1. Plan and elevation of auriferous quartz veins and exploratory tunnel on the Wetzler claims on Hurtle Creek.......

2. Sketch map to show the relation of gold-bearing veins, dikes, and development work at the Ellis claims on Boulder Creek.

3. Diagram of the Knowles gold-quartz claims on the north side of Mill Creek, a tributary of Stuart Creek ............

4. Quartz veins on the south ends of claims Bertha Nos. 1 and 2. 


\title{
GEOLOGY OF THE TONSINA DISTRICT, ALASKA
}

\author{
By Fred H. Moffit
}

\begin{abstract}
The Tonsina district is a part of the north slope of the Chugach Mountains that includes the headwaters of the Klutina, Tonsina, and Tiekel Rivers and their upper valleys. This district is an area of rugged mountains, which reach a height of over 8,000 feet in its southwestern part but are lower and less rugged toward the north, where they meet the Copper River lowland. Its principal valleys are of typical giacial form and are wooded at the lower levels. It includes two of the larger lakes of the Copper River Basin. Numerous glaciers on the high divide between the drainage flowing south to Prince William Sound and that flowing north and east to the Copper River supply most of the water of the three streams mentioned above. The largest of these glaciers, the Valdez Glacier, provided the route used by prospectors in traveling from the coast of Prince William Sound to the upper Copper River Valley and interior Alaska in the early days of the gold excitement. This route was soon abandoned in favor of the trail up the Lowe River and over Thompson Pass that later became the Richardson Highway.

This part of the Chugach Mountain area is made up of two principal groups of rocks, which are dominantly of sedimentary origin, are folded and metamorphosed in varying degree, and have the same general trend as the mountains themselves-that is, slightly north of west.

The oldest rocks of the Tonsina district are in its northern part, adjacent to the Copper River lowland, and include argillite, graywacke, quartzite, banded argillite and quartzite, and limestone. These sediments are interbedded with lava flows and tuffs and are intruded by granitic rocks that are chiefly granite and quartz diorite. All are metamorphosed in some degree and in places schistose. The bedded rocks, at least in part, are believed to have been deposited in early Carboniferous (Mississippian) time.

The southern and larger part of the district is occupied by a great thickness of slate and graywacke in alternating beds which are much folded, seamed with quartz veins, and intruded by sills and dikes of granite and quartz diorite. The sedimentary beds are believed to be of Mesozoic age, being later than the Triassic and belonging in part to late Cretaceous time. If this assignment is correct the Chugach Mountains themselves were formed during the Tertiary period, and at least a part of the intrusive granite and quartz diorite of the district are also of that age.

In much more recent geologic time the district has undergone profound glaciation, not yet ended, during which the topographic forms were modified, old deposits of gravel were swept from the valleys, and new deposits of glacial debris and waterborne material were laid down.

The Tonsina district has produced a small quantity of gold and holds promise of further production. The time of intrusion by igneous rocks was also a
\end{abstract}


time of formation of mineralized quartz veins. So far as is known at present the mineralized veins owe their value entirely to their content of gold. Their best example is the Cliff mine, near Valdez, but several areas of gold mineralization have been found within the Tonsina district, and mining development is in progress or has been carried on at a number of localities.

\section{INTRODUCTION}

The purpose of this paper is to describe the geology and mineral resources of a part of the Copper River Basin between the Richardson Highway and the valley of the Klutina River, together with small areas east of the highway and west of the river. For convenience in reference this area is called the Tonsina district, as the Tonsina River and Tonsina Lake are conspicuous local geographic features, and the Tonsina Road House, on the highway at the crossing of the river, is one of the oldest and best-known settlements in the Copper River Basin.

The Tonsina district was perhaps the first among the mineralized sections of the Copper River Valley to receive attention from the horde of gold seekers who swarmed into Alaska after the bonanza discoveries in the Canadian Klondike, for whether these prospectors, starting from the coast, crossed the glacier between Valdez and the Klutina River or made their way over the Chugach Range by the later discovered Thompson Pass, they came first into this district, where evidences of their presence and labors are still to be seen in a few places. Their efforts here, however, did not meet with the quick reward they hoped for, and with a few exceptions they moved on to more distant fields. Although this district has not become a mining center, it has not been neglected by later prospectors, and it now furnishes a route for the only highway for automobiles from the Pacific coast to interior Alaska.

\section{PREVIOUS WORK}

Topographic mapping and geologic investigation in the Tonsina district began almost with its discovery by white men. In 1898 Capt. W. R. Abercrombie, of the United States Army, was sent by the War Department to Valdez in charge of a military expedition whose object was to find a route of travel from the coast to the interior of Alaska. The first route investigated by this expedition was that over the Valdez Glacier to the Klutina River and Copper Center, for the route over 'Thompson Pass and through the Tsina and Tiekel Valleys now followed by the Richardson Highway was not then known. To this party Emil Mahlo, topographer, and F. C. Schrader, geologist, of the United States Geological Survey, were attached, and together with Lieut. T. P. G. Lowe, of the Army, they carried on topographic and geologic surveys. Their work 
resulted in a topographic and geologic exploratory or route map which shows Port Valdez and Valdez Glacier and the valley of the Klutina River, together with the part of the Copper River that lies between the mouth of the Klutina River and the Tasnuna River, and the valleys of the Tasnuna and Lowe Rivers. This map was issued as part of the account of the expedition prepared by Schrader. ${ }^{1}$

During the next few years the growing importance of mining interests in the Copper River region induced the United States Geological Survey to send topographic and geologic parties into it to further these interests and present information concerning them to the public. The first party was organized in 1900 in charge of T. G. Gerdine, topographer, and F. C. Schrader, geologist, and was concerned chiefly with mapping the Chitina Valley, but at the beginning of the season topographic surveys were carried on along the military trail, now the Richardson Highway, from Valdez to Tonsina and were extended west from the trail sufficiently to include the Tonsina River and Tonsina Lake. The reconnaissance topographic map by Gerdine appeared in a report of the season's work by Schrader and Spencer. ${ }^{2}$

No further topographic surveys were undertaken in the Tonsina district until 1931, except a survey of a small area north of Klutina Lake and a traverse of part of the Richardson Highway from Beaver Dam (now abandoned) north to Copper Center, which was made by J. W. Bagley, of the United States Geological Survey, in 1913. Theodore Chapin, geologist, accompanied Bagley's party in 1913 and collected information on the geologic formations near the lower Klutina River. Three years later I spent a short time in the southern part of the district visiting mining prospects on Quartz and Hurtle Creeks and in the vicinity of Tiekel and studying the geology of Kimball Pass. ${ }^{3}$

A system of accurate levels with permanent bench marks was established along the highway by the United States Coast and Geodetic Survey in 1922 and 1923.

\section{PRESENT INVESTIGATION}

The present investigation was undertaken with the intention to complete the topographic map of the Tonsina district, to make geologic reconnaissance surveys in a large part of it which had

1 Schrader, F. C., A reconnaissance of a part of Prince William Sound and the Copper River district, Alaska, in 1898: U. S. Geol. Survey 20th Ann. Rept., pt. 7, pp. 341423, pl. 21, 1900 .

2 Schrader, F. C., and Spencer, A. C., The geology and mineral resources of a portion of the Copper River district, Alaska: U. S. Geol. Survey Special Pub., 1901.

- Moffit, F. H., Mining in the lower Copper River Basin : U. S. Geol. Survey Bull. 662, pp. 177-182, 1918. 
never been visited by geologists, and to study its mineral resources and the mining developments which have been made in recent years. The work of topographic and geologic mapping involved the field work of two seasons. In 1931 C. F. Fuechsel, topographer, did the work on which most of the topographic map accompanying this report is based. Practically all the area west of the Richardson Highway and north of Tonsina Glacier except a small part in the northwest was surveyed that year. To this a small area in the vicinity of Kimball Pass was added in 1932.

Using this topographic map as a base for representing the areal geology, I made a geologic reconnaissance of the area between the Richardson Highway and the Klutina River and of the Kimball Pass area in 1932 but did not visit the mountains north of Klutina Lake nor the much higher mountains on the south in which the Klutina and Tonsina Glaciers lie. This work was done under somewhat unfavorable conditions, for the summer of 1932 in this district was cool and had a greater number of wet or cloudy days than is usual in this interior basin, where fair weather is more to be expected. In consequence, much snow remained in the higher mountains till late in the season, making feed for pack horses scarce and interfering with travel as well as concealing features of the geology. The field party included M. J. Knowles, packer, and Verne Robinson, cook, and was equipped with a pack train of nine horses and the necessary camp gear and supplies. For a short time at the end of the summer the geologic party was joined by Mr. Fuechsel while work in the Kimball Pass area was in progress. The field season extended from June 6 to September 5.

\section{GEOGRAPHY}

\section{RELIEF AND DRAINAGE}

The Tonsina district comprises a small part of the Chugach Mountains, the coastal range bordering the Gulf of Alaska, and lies north of the divide that separates waters flowing directly to Prince William Sound from those which find their way to the Pacific by way of the Copper River. On the south are high, rugged mountains where the accumulated snows of many years are seen in the Valdez-Klutina Glacier system, Tonsina Glacier, and many smaller glaciers. These mountains have a nearly east-west trend. They include numerous unnamed peaks having altitudes of 7,000 feet or more and reach 8,220 feet in the high point between Tonsina and Klutina Glaciers. From the divide northward the summits gradually diminish in height, the ridges become smoother, and the narrow gulches and steep-walled canyons change to broad open valleys separating lower round-topped ridges and isolated mountains. Finally, the mountain area gives 
place wholly to the broad lowland of the Copper River Basin on the north.

This district is drained by three principal streams, the Klutina, Tonsina, and Tiekel Rivers, and their various branches. These streams are all tributary to the Copper River. They derive a large part of their water from melting glacier ice, and although each has many small clear-water branches, the water of the main streams is silt-laden and has the characteristic color of glacier water.

The Klutina River rises in the system of glaciers which forms in the high Chugach Mountains and includes Klutina and Stephens Glaciers and several smaller glaciers north of Tonsina Glacier. Klutina Glacier heads against Valdez Glacier in a divide about 5,000 feet above the sea and thus formed a link in the difficult route followed by the prospectors of the early rush to the interior. The river flows north from the glacier for 15 miles to Klutina Lake through a $U$. shaped valley whose wide floor is occupied by lakes and marshes that make travel with horses in summer a practical impossibility anywhere except along the margin. This wide northward-sloping floor was formed from material dropped by the glacial streams and is slowly encroaching on the lake. Klutina Lake is 16 miles long and $21 / 2$ miles wide at its widest point at the bend. It is L-shaped and makes a right-angle turn to the east 10 miles from its head. From the outlet of the lake the river flows for more than 20 miles in a general northeasterly direction to the Copper River, most of the way occupying a deep canyon cut in the silt, gravel, and other unconsolidated deposits of the Copper River lowland. Stephens Creek, the Hallet River, and St. Anne Creek are the largest tributaries of the Klutina River system from the west, the Mahlo River and Manker Creek from the east.

The Tonsina River and Tonsina Lake resemble the Klutina River and Klutina Lake in arrangement but are on a somewhat smaller scale. The Tonsina River flows from Tonsina Glacier, which heads against Valdez Glacier but extends eastward at right angles to it. On emerging from the glacier the river flows eastward across wide gravel bars for 2 miles to a deep rock-walled canyon, which it occupies for nearly 3 miles, at one point forming an impressive waterfall. Below the canyon it turns abruptly and follows a northward course for 8 miles to Tonsina Lake. This upper valley between the canyon and lake offers even greater difficulties to travel than the upper Klutina Valley and in summer is a succession of swamps, lakes, and quicksand that can hardly be crossed by a moose. Tonsina Lake is 6 miles long and 1 mile wide. Its altitude is 1,930 feet, or 140 feet higher than Klutina Lake. The Tonsina River flows northeastward from the lake to the margin of the Copper River lowland at Tonsina and thence 
makes its way eastward in a deep canyon in unconsolidated deposits, similar to that of the Klutina River, to the Copper River. The larger tributaries of the Tonsina River from the west are Greyling and Squirrel Creeks; from the east, the Little Tonsina River, along which the Richardson Highway runs, and Quartz and Bernard Creeks.

The Tiekel River heads against the Little Tonsina near the old Ernestine road house and flows south to its junction with the Tsina River and Stuart Creek, where it turns east and flows to the Copper River through a canyon 14 miles long that lies parallel to the trend of the Chugach Mountains. The lower east-west valley of the Tiekel has never been traversed with horses in either summer or winter, and only a few men have been through it. The Tsina River, the largest tributary of the Tiekel, heads in glaciers north of Thompson Pass and flows in canyons for most of its length. Stuart Creek receives the water of several small glaciers. Its upper valley is above timber line and is open, but the lower 3 miles of the stream course is a series of waterfalls and rapids through rock-cut canyons. The Lowe River is a westward-flowing glacial stream that empties into the head of Port Valdez. It does not properly belong to the Tonsina district, but its valley is followed by the Richardson Highway. Thompson Pass (2,730 feet) between the Lowe and Tsina Rivers and the Keystone Canyon are points of special scenic interest on the Lowe River section of the highway.

The valleys of all these streams were once occupied by ice and show the characteristic features of glaciated valleys in typical form. They were straightened by the truncation of the spurs between tributary streams, their cross sections are $U$-shaped, and they head in cirques. Finally, the waste material transported by the ice that moved through them is widely distributed as morainal deposits.

\section{ROUTES AND TRAILS}

The prospectors who landed on the beach at Valdez in the fall of 1897 were bound for the interior of Alaska, and the military expedition which followed them the next year was specifically charged with the task of finding a feasible route to the interior. The first efforts of all in their attempt to cross the coastal mountain barrier were directed toward Valdez Glacier and the valley of the Klutina River. Hundreds of men and horses and many tons of freight passed over the long icy road from the foot of Valdez Glacier to the summit and down the steep slope of Klutina Glacier to the river. Some failed in the attempt, and their bodies are still entombed in the ice. The climb to the high point from the Valdez side is 5,000 feet in 15 miles, and the descent on the north side is about 3,000 feet. The air-line distance between the point of going on the ice and the point of leaving it is 
19 miles, but a greater distance was covered in the journey. The trail for pack horses below the glacier was on the west and north sides of Klutina Lake and the Klutina River as far as Copper Center. A branch trail up the valley of St. Anne Creek was later used by prospectors in the Valdez Creek district of the upper Susitna River. Another ascended Manker Creek and crossed to Quartz Creek at the lower end of Tonsina Lake. These trails are no longer in use and are now difficult to follow in places where the ground was marshy or where the vegetation has grown up in them.

Not all the traffic, however, went over the trails, for freight was also carried by boat, especially on Klutina Lake and the lower river. There the swift current and the many obstacles made boat transportation difficult and dangerous, so that some lives and a great deal of property were lost.

The Valdez Glacier route was abandoned after Thompson Pass, between the Lowe and Tsina Rivers, was discovered. The new route ascended the Lowe River to the pass, which it crossed at an altitude of 2,730 feet, and thence followed the valleys of the Tsina, Tiekel, Little Tonsina, and Tonsina Rivers to the Tonsina crossing. At Tonsina, where the margin of the Copper River lowland begins, the trail branched, one branch continuing north and west to Copper Center, the other turning east and crossing the lowland to the mouth of the 'Tonsina and so reaching the Chitina Valley. The northward branch, together with the main trail, became the Military Trail to Circle, on the Yukon. Later, after the new trail to Fairbanks was opened and the old trail beyond Tanana Crossing was abandoned, this route became part of the Richardson Highway, named in honor of Gen. Wilds P. Richardson, who was long connected with its construction as president of the Alaska Road Commission. A branch road 39 miles long, the "Edgerton cut-off", connects Chitina, on the Copper River \& Northwestern Railway, with the Richardson Highway at Willow Creek, a point midway between Tonsina and Copper Center. The Richardson Highway provides a road suitable for passenger cars and trucks between Valdez and Fairbanks, or between either of these places and Chitina. Thompson Pass, however, has not been kept open in recent winters, and for more than half of the year that part of the highway is closed to traffic. For several winters mail between the Tonsina district and the coast has been carried by airplane.

In addition to the highway there are within the district a few short local trails that lead to mining properties or are used by trappers and other foot travelers. They include trails on Stuart Creek, Boulder Creek, Hurtle Creek, the Kimball Pass section of the old military trail, and others that are seldom used by any except the local residents. 


\section{TIMBER AND VEGETATION}

Most of the land in the Tonsina district that lies below an altitude of 3,000 feet was originally covered with spruce timber, which varied in size and quality with the character of the soil on which it grew and with the conditions of moisture, temperature, and altitude. Much of it grew on cold, wet ground and was small and scrubby and suitable for nothing but firewood, but some on good ground was large and valuable for many uses. Many square miles of this timber was burned by the early prospectors and travelers, who were hindered by it in their work or were annoyed by the myriads of mosquitoes and flies which it harbored. On the lowland east of the Klutina River the bare trunks of dead trees, standing or fallen, indicate the burned-over lands as far as the eye can distinguish them, notwithstanding the young growth of small deciduous trees and shrubs that have come up. Much of the mossy ground was too wet to burn, and the fires tended to destroy the most valuable timber on the well-drained slopes rather than the poor trees. Another reason for burning the timber and especially the small brush was that the grass was given an opportunity to grow and provide forage for stock. This result may be seen in many places. Yet in spite of any benefits that may have been involved in the practice, it is true that much of a valuable resource was destroyed beyond the hope of early replacement, for trees in the north country grow slowly.

Notwithstanding the fires, a good deal of excellent timber remains that is suitable for mining work or building. Yet even this may never be used, for thousands of the finest trees have been killed or are being killed by bark beetles, which are widely distributed in the Copper River Basin. Spruce makes up by far the larger proportion of the forest trees, although balsam, poplar, and quaking aspen are common and birch is found occasionally. Dwarf birch or "buckbrush" is present throughout the northern part of the district and obstructs travel by either man or horse. It covers the lower rounded hills, is interspersed with the forest trees, and is especially abundant at about timber line in the wide upper valleys of the Mahlo River and Manker Creek. Near the coast the dwarf birch is replaced wholly by alder, which is of slight value but gives a more pleasing aspect to the landscapes. Here also the cottonwood grows to large size and forms a large proportion of the forest cover near the stream courses and on the lowland gravel bars.

The timber of the Tonsina district is not a resource of value for other than local use. It has no export value, but in view of the cost of bringing in the better lumber from the outside, it could compete with that for use in many ways, although at present there is little demand and no mill to supply the demand if it arose. 


\section{GEOLOGY}

\section{GENERAL FEATURES}

The description of geologic formations and structure that follows deals only with the more obvious features that may be noted in reconnaissance work, for the character of the rocks and the time available for studying them made it difficult to investigate many of the problems of distribution and relations. Consequently it should be stated in the beginning that some of the most important problems were not solved, and that therefore a lack of clarity in some of the descriptions will be evident.

Most of the Tonsina district (pl. 1) is occupied by rocks that were deposited in water, although part of these water-laid deposits were originally fragmental material of volcanic origin and not the usual products of rocks wearing from hill slopes and stream channels. They may be divided into two groups, which differ in age as well as in lithology and are restricted to definite parts of the district. The group of older rocks includes banded argillite and fine sandstone or quartzite, slate, graywacke, tuff, lava flows, and limestone. The rocks of this group are much folded, silicified, and otherwise altered, even being schistose in places, and are believed to be in large part if not wholly of lower Carboniferous (Mississippian) age. They are confined to the north side of the district.

The second group is dominantly argillaceous and consists of alternating beds of slate and graywacke. The beds are folded, but the rocks are less altered than those previously mentioned and are nearly everywhere cut by an intricate network of fine quartz veins. It is believed that these rocks belong to the Mesozoic era and that at least a part of them were deposited during Upper Cretaceous time.

The structural relations of the two groups of rocks are not known definitely, although it is probable that the slate-graywacke group overlies the older group unconformably.

Both groups of rocks were invaded by light-colored granular intrusives, which appear in numerous dikes, sills, and irregular bodies of larger size. The granitic rocks may belong to more than one period of intrusion, although they are not certainly known to do so. Most of the dikes and sills are probably not older than Upper Cretaceous.

Throughout the district the rocks of the two groups are broken by a persistent series of closely spaced vertical joints that strike north or nearly north and in many places contain thick veins of white quartz, some of which are gold bearing. 
UNDIFFERENTIATED CARBONIFEROUS (?) AND ASSOCIATED ROCKS

\section{CHARACTER AND DISTRIBUTION}

The undifferentiated Carboniferous (?) rocks vary widely in origin and appearance and possibly in age. The group is made up largely of altered sediments but contains interbedded fragmental volcanic material which was deposited in water yet should be distinguished from deposits that are called sedimentary in the more common, restricted sense. It also contains interbedded lava flows. The strictly sedimentary rocks were derived chiefly from muds and fine sands and now appear as argillite, graywacke, quartzite, and banded argillite and quartzite. Fine conglomerate or grit and limestone are present in a few places but make up only a small proportion of the group. Except for the limestone these rocks are commonly gray in varying shades and give a rather uniform gray aspect to the higher mountain tops, although the gray color is changed to black on the more siliceous lichen-covered rocks. The limestone beds are bluish gray in lighter hues, so that as a rule they are readily recognized at a distance. The limestone is recrystallized and commonly weathers to a coarse sand.

The tuffaceous beds and the lava flows are gray or green and are altered so that in places they are hard to distinguish with certainty. The fragments composing the tuffaceous beds do not include a large proportion of coarse material. At a typical locality on Stuck Mountain few of the fragments reach a diameter of half an inch, although some 3 -inch pieces were seen. The material at this locality plainly had been subjected to the action of moving water, for many fragments are partly rounded.

Lava flows are associated with the tuffs, but appear to be subordinate in quantity. They range in color from gray or green to nearly black and in texture from finely granular to dense.

The rocks regarded as of Carboniferous (?) age occupy the northern part of the Tonsina district (pl. 1) and are limited on the south by the younger Mesozoic rocks. A line from Ernestine to a point halfway between the head of Klutina Lake and the bend of the lake approximates the boundary between the two groups, except for the northward-projecting mass between the Mahlo River and the lake. The Carboniferous (?) rocks adjacent to the boundary are chiefly the argillite-quartzite members and the limestone. The tuffaceous beds and lava flows-that is, the volcanic rocks-lie farther north and in particular form the mountains bordering the Copper River lowland. Marshall Mountain and the ridge immediately south of the lower end of Klutina Lake consists almost wholly of lava flows and tuffs. Similar rocks form part of Mount Simpson, but from 
Manker Creek eastward the boundary rocks are all sedimentary and are noticeably siliceous. Between Manker Creek and the Tonsina River they are chiefly banded argillite and quartzite, but include argillaceous rocks that are subschistose. In many places these banded rocks have been compressed and sheared, and the beds are broken, faulted, and drawn out so that they resemble stretched conglomerate and have a mottled appearance. Where the argillaceous material is less the relative increase in quartz results in greater prominence of the quartzite beds. These rocks extend east of the Tonsina River, but there they also include limestone beds of considerable size, such as were not seen between Klutina Lake and the Tonsina. The limestone probably belongs to one rather extensive formation that is of no great thickness in the Tonsina district and has been so folded and faulted that it occurs in detached outcrops. These outcrops have a distinctly linear arrangement. The limestone continues eastward interruptedly to the Copper River and the mountains south of the Chitina, where it is much more extensively developed. Between Kimball Pass and the Copper River the limestone is exposed in many large outcrops, which have not been mapped nor searched for fossils. It is known to have a thickness of at least 500 feet at the head of a small stream coming into Kimball Pass from the southeast, where it stands vertical, and it appears as a large recumbent $\mathbf{S}$ fold in the mountains at the head of the west fork of Bernard Creek. It may be seen plainly from a long distance in the high peaks still farther east. The greatest thickness of limestone observed west of the Richardson Highway was only 50 feet. The limestone is also found north of Klutina Lake, where it is interbedded with argillaceous rocks. Chapin " describes the section east of Chultikana Creek under the heading "Klutina group" and says of it:

The dominant rocks in that section are fine-grained black slates and argillites. Interbedded with the argillaceous sediments are beds of dark-gray crystalline limestone, ranging in thickness from a few inches to 20 feet. The argillaceous rocks are fractured and seamed with quartz, which forms an intricate network of tiny stringers, and in places the rock is largely replaced by silica. The limestone throughout is more or less altered and veined with calcite. Silicification of the limestone has formed irregular masses and beds of white cherty rocks, a product of the complete replacement of limestone by silica.

The volcanic rocks, tuff's, and lava flows are well developed in the Stuck Mountain mass, in the mountains south of Klutina Lake, and in the mountains east of Tonsina. The age of these volcanic rocks

\footnotetext{
- Chapin, Theodore, The Nelchina-Susitna region, Alaska: U. S. Geol. Survey Bull 668 , p. 22, 1918 .
} 
is not definitely established (see p. 14), but their appearance and diversity of character raises a question as to the possibility that some of them may be younger than Carboniferous.

\section{THICKNESS AND STRUCTURE}

Geologic field work in the Tonsina district in 1932 yielded little evidence on either the thickness or the structure of the bedded rocks referred to the Carboniferous (?). It is plain, however, from the extent of the area occupied by them and the relief of the district that the thickness is considerable. These bedded rocks are regarded as the westward extension of the Strelna formation (Mississippian) of the Chitina Valley, which is made up of volcanic and sedimentary beds with many granitic intrusives and is believed to have a thickness of at least 6,500 feet. Probably the Strelna formation includes a greater thickness of bedded rocks than is to be found in the Tonsina district.

The absence of easily recognized reference beds in any of the formations of the Tonsina district makes it difficult to interpret their structure or determine the relations between them. The bedded rocks, being the oldest in the district, have had the greatest opportunity for change. They are folded and faulted and in places are almost schistose. The sedimentary members on the south appear to pass beneath the volcanic members on the north. Definite contacts of the Carboniferous (?) rocks with the younger slate-graywacke series to the south were not recognized, but evidence was found to indicate either that beds of the slate-graywacke series are folded into the older rocks or that erosion has left islands of the younger rocks surrounded by older rocks near the boundary line. It seems most probable that the relation between the two formations is one of unconformity. The age relations alone would suggest this.

Faults are difficult to recognize where marked contrasts in color or other characteristics are lacking in the beds, but they become conspicuous where limestone is present or where dikes and sills of light-colored intrusive rock cut them. The limestone bed that lies near the south boundary of the Carboniferous (?) rocks is broken into discontinuous masses that may be due in part to erosion or original deposition but are certainly in part the result of faulting.

In addition to the fractures that are designated faults, a system of joint planes is highly developed throughout the Tonsina district and is the most prevalent and conspicuous structural feature to be seen. These planes are closely spaced, show little variation from a north-south trend, and in general are nearly vertical, dipping steeply east or west. Joints with other dips and strikes are seen, but they are few in comparison with the north-south vertical joints. For 
some unknown reason, as shown on page 36, this north-south system of joint planes is the most favorable place for mineralized quartz veins in this district.

\section{AGE AND CORRELATION}

The group of bedded rocks that has just been described is here assigned provisionally to the Carboniferous (?), although paleontologic evidence for this assignment has not been found in the Tonsina district. These rocks are regarded as the direct westward extension along their strike of a similar group of rocks which is exposed in the Chitina River Valley throughout most of the distance from the Copper River to the international boundary. The rocks of this group were studied by Moffit and Mertie ${ }^{5}$ at a typical locality in the Kotsina-Kuskulana district and were there called the Strelna formation. They comprise highly altered sediments, including one or more limestone beds, and bedded volcanic rocks, together with intrusive rocks of various kinds. Although the limestone is much folded, faulted, and recrystallized, the alteration has not gone far enough to destroy all the fossils contained in it. Fossils collected from limestone in the Kotsina-Kuskulana district and the upper Chitina Valley were determined by G. H. Girty ${ }^{\circ}$ to be of Mississippian age. A small collection of fossils from limestone on Nerelna Creek near Taral, south of the Chitina River, was determined to be Carboniferous ${ }^{7}$ but was lacking in diagnostic forms that would permit a closer determination. However, as all the paleontologic evidence so far obtained points to the absence of marine sediments of Pennsylvanian age in Alaska, except possibly at one doubtful locality in southeastern Alaska, the limestone near Taral is also probably of Mississippian age. The limestone of Nerelna Creek extends west of the Copper River and is believed to be the equivalent of that near Kimball Pass and north of Quartz Creek in the Tonsina district. On this basis, as well as that of lithologic similarity and the structural relations, the limestone and part if not all of the other sedimentary rocks associated with it are regarded as Carboniferous and probably of Mississippian age. No evidence of any kind was found to suggest a correlation with the Permian rocks of the Nizina district.

The rocks north of Klutina Lake were not examined by me but are included among the Carboniferous sediments, as they are lithologically similar and lie in strike with them. They make up the

\footnotetext{
Bofft, F. H., and Mertie, J. B., Jr., The Kotsina-Kuskulana district, Alaska: U. S. Geol. Survey Bull. 745, p. 21, 1923.

- Moffit, F. H., and Overbeck, R. M., The upper Chitina Valley, Alaska: U. S. Geol. Survey Bull. 675, p. 21, 1918.

${ }^{7}$ Moffit, F. H., Geology of the Hanagita-Bremner reglon, Alaska: U. S. Geol. Survey Bull. 576, p. 20, 1814.
} 
Klutina "series" of Schrader, ${ }^{8}$ which, on the meager evidence available at the time he saw them, he regarded as of pre-Silurian age. Chapin ${ }^{\circ}$ was the first to regard them as Carboniferous, althongh admitting a possible pre-Carboniferous age.

The age of the volcanic rocks of Stuck Mountain and several isolated hills west of the Klutina River is more uncertain than that of the limestone and associated sediments. On the basis of lithologic similarity these tuffs and lava flows were correlated by Chapin ${ }^{10}$ with Lower Jurassic volcanic rocks on Tyone Creek, in the Nelchina district, 55 miles northwest of Klutina Lake. No conclusive evidence for the age of the volcanic rocks of Stuck Mountain was obtained by either Chapin or me, yet as no evidence was found to indicate that they should be differentiated from similar volcanic rocks included in the Carboniferous of nearby localities, they have not been separated from the Carboniferous (?) rocks in this description or on plate 1. It is recognized, however, that Chapin's interpretation may eventually prove to be correct.

In concluding this section it may be said that all the rocks of the Copper River drainage basin that have yielded Paleozoic fossils sufficient in number and kind to be of diagnostic value are now referred with considerable assurance to the Mississippian epoch of the Carboniferous period except the Permian rocks of the upper Copper River and the upper Nizina River. Yet the facts that fossils have been collected only from limestone, which forms a minor part of the bedded deposits referred to the Carboniferous, and that these deposits are not only of wide distribution but of great thickness make it unsafe to assume that the areas mapped as Carboniferous(?) in the Tonsina district do not include rocks that are older or younger than Mississippian.

\section{INTRUSIVES IN THE BEDDED ROCKS}

The bedded Carboniferous(?) rocks are intruded by dikes, sills, and irregular-shaped bodies of quartz diorite and granite, ranging from a fine-grained white rock without dark minerals to coarsely porphyritic granular rock or coarse even-grained rock made up of nearly equal parts of light and dark minerals. Much less common is a coarsely granular intrusive made up almost wholly of hornblende or other dark mineral.

The dikes and sills of granitic intrusive rock are distributed throughout the area in both the Carboniferous(?) and Mesozoic

\footnotetext{
${ }^{8}$ Schrader, F. C., A reconnaissance of a part of Prince William Sound and the Copper River district, Alaska, in 1898: U. S. Geol. Survey 20tb Ann. Rept., pt. 7, p. 410, 1900.

- Chapln, Theodore, The Nelchina-Susitna region, Alaska: U. S. Geol. Survey Bull. 668, p. $22,1918$.

${ }^{10}$ Idem, p. 29.
} 
rocks and are usually readily distinguishable at a distance because of their light color, which stands in contrast with the dark of the host rock.

Much larger masses of granular igneous rock are found in the vicinity of Squirrel Creek. The ridge between Rock and Squirrel Creeks, Mount DuRelle, and the mountain between the forks of Squirrel Creek, together with some adjacent spurs on the south, are all quartz diorite, but whether these apparently isolated areas are distinct bodies in the sedimentary rocks or are elevated parts of a single body in which the Squirrel Creek Valley is cut is impossible to determine, because of the gravel deposits that occupy the lowlands and hide the underlying rock. The topographic relief of these masses, however, suggests that they are probably distinct though related bodies from which the less resistant bedded rocks have been removed by erosion.

A large body of granitic intrusive rock forms the mountain at the north end of the ridge between the Little Tonsina River and Bernard Creek. This body is more complex than those in the vicinity of Squirrel Creek and consists in large part of rocks that are much more basic than the quartz diorite of Squirrel Creek. This mountain and also the mountain east of it on the far side of Bernard Creek are conspicuous for their rusty appearance, a result of the oxidation of iron-bearing minerals. The west side of the mountain west of Bernard Creek shows rocks that are dark, heavy, and fine to coarsely granitic in texture. Specimens from which thin sections were cut were determined as gabbro and dunite. The dunite consists wholly of olivine partly altered to serpentine. Similar basic rocks crop out on the Bernard Creek side, but the granitic rocks near Kimball Pass are quartz diorite.

The age of the intrusives in the bedded Carboniferous (?) rocks is not fully known. Some if not all of the dikes and sills are of the same age as those in the Mesozoic slate and graywacke and are therefore probably late Cretaceous or post-Cretaceous. On the other hand, the large bodies of quartz diorite and more basie rocks may be much older. None of them occur within the area of Mesozoic sediments, and all show some degree of alteration. The degree of alteration, however, is not regarded as sufficient evidence for relative age determination. It is possible that some of the granitic rocks may be as old as early Carboniferous, although they necessarily are younger than the rocks into which they were intruded.

\section{CRETACEOUS (P) AND ASSOCIATED ROCKS}

CHARACTER AND DISTRIBU'TION

More than half of the area represented on the geologic map of the Tonsina district is occupied by sedimentary rocks, which include little $124011-35-3$ 
besides beds of slate and graywacke seamed with quartz veins and cut by numerous dikes and sills of diorite porphyry. Beds of grit or conglomerate are present here and there but are small and rather inconspicuous. No limestone whatever was seen. These rocks occupy all the area south of the Carboniferous (?) bedded rocks and are doubtless the most extensive geologic member of the Chugach Mountains in this district. They range from gray to black but are without strong contrast in color and in consequence present a remarkable monotony of exposures, lacking in outstanding evidences of bedding and structure. Close examination shows that the beds differ chiefly in the coarseness of the material composing them and makes it evident that the slate and graywacke must have been derived from a common source. The formation was built up of innumerable alternating beds of mud and dark sand ranging from a few inches to many feet in thickness, but the alternation of fine and coarse material appears not to have been sufficiently rapid or the beds sufficiently uniform in thickness to produce the ribbon structure seen in the slate and graywacke parts of the Alaska Range and in the Carboniferous (?) slate and quartzite beds of the Tonsina district. Induration and further alteration changed these beds of mud and sand to slate and graywacke. Locally alteration has gone still further, and the slate and graywacke have become phyllite or even schist.

Throughout most of the Tonsina district the slate and graywacke are seamed with fine white quartz veins which give them their most outstanding feature. These veins fall into two groups. The veins of ane group follow the bedding or cleavage planes of the sediments and appear to be folded and contorted like the bedding. The other veims cut across cleavage and bedding at various angles and are made up. of thin sheets of white quartz which show on a joint face as parallel straight lines. In both groups the quartz veins are thin, many being of only paper thickness and most of them measurable in fractions of an inch. Most commonly the joint planes of the slate and graywacke show a grid or network of intersecting quartz veins of remarkable regularity in spacing and straightness.

Quartz veins of another variety, probably younger, are not so common as the fine veins just described but are more conspicuous in large exposures of the country rock when viewed at a distance. This system of veins, which range in thickness from less than 1 foot to 10 feet or more, for the most part follows the north-south joint planes. These veins are of lenticular form. Few of them are known to extend more than 100 or 200 feet in the greater horizontal direction, and it is believed that a corresponding limitation of the vertical dimension is to be expected. Probably such veins are more numerous in certain wide zones of fracture and thus have a suggestion of linear arrangement, but observation of many occurrences 
appears to establish beyond question that the individual veins throughout the area have a lenticular habit and in general may not be expected to continue for long distances in any direction. This fact is of economic importance, as some of these veins show a high tenor in gold.

\section{THICKNESS AND STRUCTURE}

The slate-graywacke series of sediments is lacking in beds that can be recognized from place to place and that would give a clear indication of the structure of the formation as a whole. In a few places exceptionally large and fine exposures show the bedding on a large scale. The mountains in the vicinity of the divide between Quartz and Hurtle Creeks give one such opportunity for observation but, contrary to expectation, show only moderate folding at this place. In general, however, it is believed that the beds are much folded and are extensively faulted, as is shown by broken and displaced quartz veins and diorite dikes.

The thicliness of the formation is not known, for neither the top nor the bottom has been recognized with certainty, nor has the work been sufficiently detailed to provide data for determining it. The rocks form a large part of the Chugach Mountains, which in this part of Alaska are about 100 miles wide. These rocks are closely folded and deeply eroded. Because of their wide distribution and the relief of the mountains which they form, the conclusion seems unavoidable that their thickness must be measured in thousands of feet.

\section{AGE AND CORRELATION}

The slate-graywacke formation of the southern Tonsina district is part of a succession of sedimentary beds which Schrader ${ }^{11}$ studied on Prince William Sound in 1898 and described as the Valdez "series." He correlated these rocks with the $\nmid$ Sunrise series, ${ }^{12}$ which Mendenhall ${ }^{13}$ saw on Turnagain Arm, in the upper Cook Inlet district, but neither he nor Mendenhall was able to find conclusive evidence for their age.

One of the astonishing features of this great series of sediments, which is exposed over thousands of square miles of mountains included in the Chugach Range, is the paucity of the organic remains that characterize it. For many years the known evidences of ancient life consisted chiefly of trails of worms and crustaceans and fragmental plant remains. From time to time a few shells of mollusks

\footnotetext{
11 Schrader, F. C., op. cit. (20th Ann. Rept., pt. 7), p. 408.

12 A dagger $(t)$ preceding a geologic name indicates that the name has been abandoned or rejected for use in classiflcation in publications of the U. S. Geological Survey. Quotation marks, formerly used to indicate abandoned or refected names, are now used only in the ordinary sense.

1 Mendenhall, W. C., A reconnaissance from Resurrection Bay to the Tanana Biver, Alaska, in 1898: U. S. Geol. Survey 20th Ann. Rept., pt. 7, p. 305, 1900.
} 
in widely separated localities were found by later workers, and the conviction grew that at least a part of the slate-graywacke group was of Mesozoic age and probably high in the Mesozoic. During the field season of 1932 Park $^{14}$ collected fossils from several localities north of Turnagain Arm which were determined by J. B. Reeside, Jr., as Cretaceous and probably Upper rather than Lower Cretaceous, thus confirming the previous conviction. Although these localities can represent only inadequately the great mass of sediments involved, it seems evident that the Valdez group and part of the $\nmid$ Sunrise series are Cretaceous, at least in part, and on this basis the slate-graywacke rocks of the Tonsina district are referred tentatively to the Cretaceous, with the realization that they may inclure older rocks.

\section{INTRUSIVES IN THE CRETACEOUS (?) ROCKS}

Throughout the Tonsina district the beds of the slate-graywacke sequence, like the Carboniferous (?) rocks, are cut by light-colored pornhyritic dikes and sills of quartz diorite and granite, but no large bodies of intrusive rock like those of Squirrel Creek and Kimball Pass are known. In most places the igneous rock is finely granular and without dark minerals. The phenocrysts are small, rather inconspicuous crystals of feldspar, which are best seen when light is reflected from the cleavage planes. In some of the dikes small needlelike crystals of hornblende are either distributed evenly through the rock or less commonly are grouped in small bunches.

These dikes and sills contrast strongly with the dark slate and graywacke beds and are conspicuous on cliffs and bare-rock areas. Some of them, like the large quartz veins, follow north-south joint planes, although they are not confined to such planes. It seems probable that a genetic relationship exists between the intrusion of dikes and the formation of the quartz veins. Both dikes and veins are thought to indicate the presence of deep-seated bodies of igneous rock from which the dikes were derived and the vein-forming solutions received the stimulus for circulation and probably their substance.

The time of intrusion of the dikes is known only within wide limits. If the slate and graywacke are Upper Cretaceous, as seems most probable for at least a part of them, the dikes are Upper Cretaceous or later. Sandstone and shale of Upper Cretaceous age on the north side of the Chitina Valley are intruded by porphyritic dikes of quartz diorite, as are also the slate and graywacke of the area south of the Chitina River, which form the eastward extension

\footnotetext{
14 Park, C. F., Jr., The Girdwood district, Alaska: U. S. Geol. Survey Bull. 849-G, p. 393,1933 .
} 
of the slate and graywacke of the Tonisina district. Rocks of Tertiary age in the Alaska Range and in other parts of Alaska were invaded by granitic intrusives, including quartz diorite and granite. Although intrusion of Upper Cretaceous sediments is established for parts of the Copper River Basin, no evidence is known by which to determine whether the intrusion in the Tonsina district took place in Mesozoic or Tertiary time.

\section{QUATERNARY DEPOSITS}

The Quaternary deposits include unconsolidated materials such as mud, sand, gravel, and rock debris of all kinds, left on the hill slopes or deposited by water and ice in the lowland areas. Such deposits show a wide diversity of origin and appearance, but the different kinds were not differentiated in the field work and are represented by one color on plate 1 . All this loose material is the product of erosion of the country rock under the action of water, ice, wind, temperature changes, and chemical processes. Some of this waste lies near the source from which it came, and some has been transported for many miles. Some is angular and shows little effect of water other than that of the rain that washed it; some has been sorted according to size or weight and is rounded by the currents of lakes and streams.

As deposits of wind-borne material are of small amount in this district, the unconsolidated deposits may be classified as those that were transported by water and laid down in water and those that were ice-borne and were deposited when the ice melted, but the two processes have been so intimately associated that it is difficult to find large deposits which belong strictly to either class. Both ice and water have at some time had a part in the formation of nearly all the unconsolidated deposits.

Each stream at some place in its course is engaged in one of several processes. It may be actively cutting its bed, either the solid rock or loose material; it may be chiefly engaged with the transportation of material; or it may be dropping a load it is no longer able to carry. The net product is some form of unconsolidated deposit. The stream sand and gravel form the present flood plains but also make up benches and terraces that now stand above the reach of flood waters, although representing the flood plains of earlier stages of the stream's history. Such deposits are found everywhere throughout the district and in part are the product of recent stream erosion but to a much greater extent are reworked material furnished by glaciers. The upper valleys of the Klutina and Tonsina Rivers illustrate this process well. Both valleys above the lakes are flooded with loose material, which consists of debris that was brought down from the high moun- 
tains by the ice, was delivered to the streams, and was transported by them as far as they have been able to carry the load. The valley floors are encroaching on the upper ends of the lakes by the deposition of the coarse material at the river mouths, and the lakes are filling through the deposition of the finer material, which is carried in suspension in the currents but is given up in the quieter waters. Unless. this process is interrupted the lakes must eventually disappear.

Glacial deposits as here considered include not only such deposits as result when glacial ice melts and leaves its load of debris at the place of melting but also material that was deposited by ice and has undergone more or less sorting by water. Such deposits are widespread and make up most of the unconsolidated deposits of the Copper River lowland and the lower ends of the valleys opening into it. The Klutina and Tonsina Rivers have cut their canyons several hundred feet into such deposits, which consist largely of an irregular assortment of silt, sand, and gravel, although more or less glacial till containing angular blocks is present.

Strictly morainal deposits of typical topographic form are not particularly noticeable in most of the district and where found are chiefly lateral moraines along the mountain sides. They occur especially in small lateral valleys where lobes of the larger ice streams entered after the small valleys ceased to be places of ice accumulation. In places a succession of lateral moraines is present, such as those that may be seen near the little lake on the divide between Manker Creek and the Tonsina River opposite the mouth of Rainbow Creek.

Well-developed terminal moraines are few, for debris laid down at the end of a glacier is particularly likely to be attacked by the streams coming from the ice and destroyed. Terminal and lateral moraines were seen at several localities between the Tonsina and Klutina Rivers, but the best examples were found in the valley of Bernard Creek. A small loop of terminal moraine was left where a lobe of ice flowed through the pass between the forks of Bernard Creek, and larger concentric moraines were left by the ice in the first valley northwest of the little lake in Kimball Pass. Morainal deposits are conspicuous also about the forks of Bernard Creek, but the heads of the valleys of these branches were swept clean of such debris.

Deposits which are a combination of stream and morainal deposits are common as a filling in the mouths of small valleys tributary to the main valley. They represent accumulation that took place when the main valleys were still occupied by ice that closed the mouths of the tributaries and furnished a dam behind which the deposits were impounded. The streams flowing from these side valleys have cut deep channels through the deposits. 
The morainal deposits help to give an idea of the extent of former glaciation and the enormous work of erosion and transportation performed by glaciers, and they present many puzzling problems relating to the movement of the ice and the source of the rock debris which the ice carried.

\section{STRUCTURE}

Much of what is known of the structure of the two bedded formations of the district has been discussed in describing those formations, but a summary of the structure of the district as a whole is desirable, even at the risk of some repetition. Unfortunately a satisfactory account of the structure is impossible with the information now available, even when neighboring areas are called on for additional evidence.

Reference to plate 1 will show that within the Tonsina district the trend of the boundary between the Carboniferous (?) and Cretaceous (?) sediments is approximately west-northwest. In general the strike of the beds of these formations is much the same as the trend of the boundary, but wide variations from this trend are found locally. In the northern part of the area, between Klutina Lake and Tonsina, most of the observed strikes of bedding range from N. $65^{\circ}$ W. to $\mathrm{N} .85^{\circ} \mathrm{W}$. The cleavage, which is not always clearly distinguishable from bedding, may coincide with the bedding planes or differ sharply from them, so that cleavage strikes of $\mathrm{N} .15^{\circ} \mathrm{W}$., $\mathrm{N}$. $30^{\circ} \mathrm{W}$., and $\mathrm{N} .40^{\circ} \mathrm{E}$. were read. Within the area of Mesozoic slate and graywacke making up the southern part of the district strikes of bedding ranging from $\mathrm{N} .65^{\circ} \mathrm{E}$. to $\mathrm{N}$. $75^{\circ} \mathrm{E}$. were read, but the observations were not sufficiently numerous to establish this as the prevailing strike, in view of the fact that variations from this trend were noticed. The cleavage, on the other hand, seems rather definitely to be prevailingly west-north west. It appears that a difference in general strike probably exists between the Carboniferous (?) and Cretaceous (?) sediments, suggesting an unconformity between them, yet a discordance of structure has not yet been established.

The Carboniferous (?) rocks are folded and much faulted. The observed dips are dominantly to the north, and no evidence of overturned folds was seen. This would indicate that the lower and older beds of the Carboniferous (?) are on the south, adjacent to the Cretaceous (?) slate and graywacke. The Cretaceous (?) rocks also are folded and faulted, but the folding was less intense than that of the Paleozoic rocks and of these same rocks on Prince William Sound.

The relation of the Cretaceous (?) beds to the Carboniferous (?) beds is not clear. In several places masses of slate and graywacke 
that may be of Cretaceous age occur within the area of Carboniferous (?) rocks and are folded into them. These areas are near the contact of the two formations and may be faulted into their present position, but their appearance suggests rather that they were deposited on the older rocks.

The relations of these same rocks have been studied in the district south of the Chitina River. ${ }^{15}$ In the Hanagita Valley and on the Tebay River the slate and graywacke seem to be separated by a fault from the Carboniferous schist and limestone in some places and to overlie them unconformably in others. In the Tonsina district the relation seems to suggest unconformable deposition rather than faulting.

The impression of geologic structure produced on studying the distribution of the rocks in the field is that of two areas of folded, bedded formations lying adjacent to each other and separated by a structural unconformity. One of these areas includes large masses of intrusive granitic rocks that are easily distinguished and consequently easily mapped, but both areas are lacking in beds that can be recognized from place to place and so furnish evidence for determining the general structure of the district. Only careful detailed surveys could supply this evidence.

\section{GEOLOGIC HISTORY}

The Tonsina district is only a part of a much larger area with a highly complicated geologic history and does not in itself furnish easily recognized evidence for many of the events that concern it: Moreover, the evidence that is presented is largely obscure and difficult to interpret, except that which has to do with glaciation and the most recent events. The following account of the geologic history is therefore generalized and incomplete.

The oldest rocks of the district are marine sediments of probable lower Carboniferous (Mississippian) age interbedded with tuffs and lava flows. These deposits indicate the presence of the sea and deposition on the sea bottom of material that consisted largely of mud and fine sand, together with a little lime. They also indicate, by the presence of tuff and lava, that deposition of the sediments was interrupted at times by the activity of volcanoes that threw out fragmental material and by the welling-out of molten lavas. The evidence of such volcanic activity is more abundant in the Chitina River Valley than in the Tonsina district.

The long interval of geologic time that elapsed between the deposition of the rocks that have been assigned tentatively to the Carboniferous period and that of the rocks assigned tentatively to the later

\footnotetext{
${ }^{16}$ Moffit, F. H., Geology of the Hanagita-Bremner reglon, Alaska: U. S. Geol, Survey Bull. 576, A. 35, 1914.
} 
part of the Cretaceous is not known to be represented by any sediments within the area under consideration, although it is known that Triassic, Jurassic, and Lower Cretaceous sediments occur in nearby areas and that these sediments were deposited, indurated, folded, elevated above the sea, resubmerged, buried under Upper Cretaceous sediments, and finally reelevated. If later Carboniferous or earlier Mesozoic sediments were laid down they either have not been recognized or have been removed by erosion.

During this long interval, however, many changes must have occurred. The Carboniferous(?) beds were deformed and probably were intruded by granitic rocks before the younger slate and graywacke were deposited. This indicates the action of mountain-building forces and also suggests the possibility that they may have been above sea level during some part of that time. The alteration observed in the Carboniferous (?) rocks is another indication of this possibility for these rocks show a greater degree of folding and more chemical change, represented by silicification and recrystallization, than the Mesozoic rocks. Possibly volcanic activity preceded the deposition of the Cretaceous(?) slate and graywacke, for evidence of such activity is recognized in localities as near as the Talkeetna Mountains on the west and the Chitina Valley on the east, where fossiliferous tuffs of Jurassic age are known.

The Carboniferous (?) rocks were eventually submerged, for the next younger rocks of the Tonsina district are also marine sediments that are regarded as probably of Upper Cretaceous age, at least in part. The composition of the Mesozoic slate and graywacke bears evidence of long-continued and rapid erosion of a nearby land mass under conditions that were relatively stable except for such changes as brought about the alternation of beds of mud with dark feldspathic sand. These deposits, which under the processes of induration and alteration became slate and graywacke, were subjected to great deforming forces, which folded and faulted them. They were invaded by molten rock, which we see now as dikes and sills, and were injected with an enormous quantity of silica, which crystallized in fracture planes and forms the vast network of quartz veins that has been described. Probably the formation of quartz veins took place at two or more periods, for the veins in the foliation of the beds may be earlier than the network of thin straight veins, and the large goldbearing veins appear almost certainly to be younger.

When the district emerged from the sea, probably in late Mesozoic time, erosion began immediately, and so far as any evidence furnished by the Tonsina district is concerned it has continued to the present. This, of course, includes a long period of subaerial erosion, during which the present mountains and valleys were at least blocked 
out, and a period of ice erosion and filling, which modified profoundly the forms of these mountains and valleys and is still in progress. No Tertiary rocks are recognized in the Tonsina district, yet here again the evidence of other parts of the Copper River Basin indicates a time of accumulation of terrestrial deposits and, in the Wrangell Mountain area, the pouring out of thousands of feet of lava beds.

At the time of maximum glaciation most, if not all, of the Tonsina district was buried in ice. Only the high peaks to the south could have stood above the surface. Stuck Mountain and all the mountains in that part of the district were ice-covered, as is shown by the gravel and erratic boulders which were left on their tops and by the grooves and striae made by the ice that moved across them. With the beginning of glaciation the ice streams flowed from the surrounding mountains toward the Copper River lowland, uniting along the mountain fronts and gradually encroaching upon the basin. At the time of maximum glaciation the basin was probably filled and became part of the area of accumulation and distribution from which the ice moved north, west, and south through the available gaps in the mountain barriers. After a time this process was reversed, the supply of snow diminished, and the ice streams retreated gradually to their present positions or disappeared altogether. During all this time the Copper River Basin received an immense quantity of waste, which accumulated for many thousands of years and was laid down not as uniform sheets covering the whole area but as overlapping lenses of assorted and unsorted material, located according to the position of the transient ice or streams or lakes that deposited them. The depth of this material in the lowland area is not known, for no streams have cut through it to the underlying bedrock. The deposits are frozen in many places, if not everywhere, and do not permit any underground circulation of water, as has been shown by the attempts to get a supply of water from wells.

Within the mountain area of the Tonsina district the valleys were well scoured out by the ice, and the unconsolidated deposits even of the larger valleys probably nowhere have the depth of the deposits in the Copper River lowland. The largest deposits are benches produced by the impounding of sand, gravel, and other less well sorted debris behind ice barriers. The Mahlo River, Manker Creek, and Greyling Creek have conspicuous deposits of this kind, and the mouths of the smaller tributary valleys show many examples of them. The typical hummock and kettle topography of many glaciated areas is practically absent in most of this district.

In many places the direction of movement of the ice was not the same throughout the period of glaciation but, like the rate of movement, was influenced by numerous factors, such as a variable supply 
of snow at a given locality, relative changes of supply in different localities, and differences in rates of melting. The result of all these varying factors was that the ice streams were in a constant condition of change. Their fronts advanced or receded temporarily, one advanced while another retreated, one stream invaded the territory of another, tributary streams failed and their valleys were invaded by the main streams, lakes were formed and destroyed, streams for a time held courses across spurs and ridges or they shifted their channels in the valleys. The occurrence of these changes is shown by the distribution and character of glacial debris and by erosion features. In some places the boulders in the glacial debris are such that the place of their origin can be determined, or at least it can be demonstrated that they must have originated outside the neighborhood of their present location. I was shown fossils from a limy argillite boulder in a gravel pit on the Richardson Highway 1 mile south of the mouth of the Little Tonsina River, of a kind of rock which has never been found in place in the Tonsina district and is not known to be present in any locality nearer than the Chitina River Valley, the upper Susitna River, or the Alaska Range, still farther away. This boulder was associated with boulders of granite that were also of foreign origin, and it therefore seems clear that the till of this locality was brought to its present position by ice moving down from the north or east. The temporary presence of a stream in a place where it is impossible for one to exist under present conditions is proved by channels cut in bedrock across ridges and especially spurs between valleys high above the valley floors. These channels have no relation whatever to present drainage and plainly must belong to a drainage system that no longer exists. Short, narrow canyonlike channels as much as 50 feet deep, floored with stream-worn gravel, cut across spur ends, and at one place several channels at slightly different levels are present on the end of a long spur between two tributaries of Manker Creek. These channels were formed when the valleys were filled with ice and the streams flowed along its margin or spilled over the barriers that confined it. Ice erosion, ice barriers, and barriers formed by the deposits laid down by the ice of the streams coming from the ice have in places caused the diversion of stream courses, either temporarily or permanently. A conspicuous example is afforded by the stream draining the upper part of the Manker Creek Valley. The natural course of this creek is northward through the lower Manker Creek Valley to the Klutina River, but the water has been diverted so that now the drainage of the upper valley is eastward through a deep, strongly glaciated cross valley to Greyling Creek and Tonsina Lake. This diversion was brought about by a combination of factors, the chief of which are 
that glacial erosion lowered the floor of the cross valley practically to the level of the Manker Creek Valley and that the filling of gravel in Manker Creek raised the bed of that stream. The adjustment of levels is now so close that in time of high water some of the water of the upper Manker Creek Valley seeks its natural outlet through the lower valley to the Klutina River, although most of it flows into Greyling Creek.

\section{MINERAL RESOURCES}

So far as is known at present, gold is the only metal that bolds out to the prospector in the Tonsina district a hope of profitable production. Furthermore, past experience would indicate that the Mesozoic slate-graywacke rocks give greater promise of yielding gold than the older Carboniferous (?) rocks, though why this should be true is not evident. The slate-graywacke formation constitutes the principal geologic member of the Chugach Range and throughout the area where it occurs is characterized by the presence of gold in amounts that range from a mere trace to deposits of commercial value. The gold occurs in quartz veins without notable amounts of other metallic minerals of value or in placers derived from the veins. In all the localities where gold is known the slate and graywacke of that vicinity are cut by dikes and sills of quartz diorite porphyry or granite. 'This association is so general that it suggests a genetic relationship between the auriferous quartz veins and the intrusive rocks. Some of the veins are remarkably rich in gold, although most of these rich veins have proved to be disappointingly small.

The best-known example of a productive gold quartz vein of this kind in the slate-graywacke formation is that of the Cliff mine, on Port Valdez. The gold placers of the 'Turnagain Arm district; of Mineral Creek, near Valdez; and of Golconda Creek, tributary to the Bremner River, are all within the area of slate-graywacke rocks.

An account of mining in the Tonsina district was given in an earlier publication, ${ }^{16}$ after a short visit to the prospects under development in 1916. Since then further discoveries have been made and additional development has taken place. Present interest centers largely in three groups of claims that lie in the mountains between Tiekel Road House and the upper Tonsina River. Although they belong to one general locality, these claims are situated in different valleys (Hurtle Creek, Boulder Creek, and Stuart Creek) and will be described separately. (See pl. 1.) The distance between the most widely separated of the groups is a little less than 5 miles. The three groups of prospects have three principal characteristics in

\footnotetext{
${ }^{16}$ Moffit, F. H., Gold lodes in the Tiekel district: U. S. Geol. Survey Bull. 662, pp. 177, $182,1918$.
} 
common. They are all auriferous quartz reins whose location was determined by the north-south system of joint planes; they show like mineral composition, although varying widely in the proportions of the different minerals; and they are associated with dikes of quartz diorite and granite.

\section{HURTLE CREEK}

Hurtle Creek is a northwestward-flowing tributary of Tonsina Lake. It heads against Boulder Creek and has two branches of nearly equal size which come together $31 / 2$ miles from the lake. The length of the creek measured on either branch is about 8 miles. Hurtle Creek may be reached by a little-used pack trail that leaves the Richardson Highway 3 miles north of the Tiekel Road House, crosses the divide to the east branch of Hurtle Creek, descends this branch, and then turns south up the west branch. The distance by trail from the highway to the property to be described is alout 9 miles.

Several groups of claims, one of which is said to be patented, have been staked by different persons on Hurtle Creek, but the group on which most work has been done lies on the east side of the west branch, $21 / 2$ miles from the forks. The claims are now the property of Charles Wetzler, who, however, may have partners unknown to me. They are situated above timber line on the lower slope of the mountain, at 4,000 feet above sea level, or 2,070 feet above Tonsina Lake. These claims are in an open valley on a moderately sloping hillside. The country rock of the general locality consists of slate and graywacke cut by a multitude of fine quartz veins, but at the place under consideration it consists of gray crinkly or satiny slate and sheared graywacke that is locally schistose. The strike of the cleavage is $\mathrm{N}$. $75^{\circ} \mathrm{W}$., and the dip is $50^{\circ} \mathrm{S}$. These rocks are broken by vertical joint planes striking $N$. $5^{\circ} \mathrm{W}$. and dipping steeply east, which contain mineralized quartz veins. About 500 feet east of the vein area is a sill of white porphyry 8 feet thick, dipping $50^{\circ} \mathrm{S}$., in bluish-gray slate or schist. The sill is offset by small transverse faults and appears to be separated by a fault plane from the underlying slate. The whole area gives evidence of extensive faulting and pressure disturbances.

Two principal mineralized quartz veins are the object of interest at this place. (See fig. 1.) These veins are parallel to each other, strike N. $5^{\circ} \mathrm{W}$., $\operatorname{dip} 60^{\circ} \mathrm{E}$, and are separated by 30 feet of the country rock. Each vein is exposed in an open cut for about 100 feet, and the two overlap each other in such a way that the distance from the north end of the west cut to the south end of the east cut is about 200 feet. The veins consist of rusty white quartz containing 
metallic sulphides, which in places are oxidized, leaving only the iron-stained cavernous quartz. They are of practically the same size as exposed in the open cut and show some variation in thickness, reaching a maximum of more than a foot. The west vein appears to be somewhat more highly mineralized than the other.
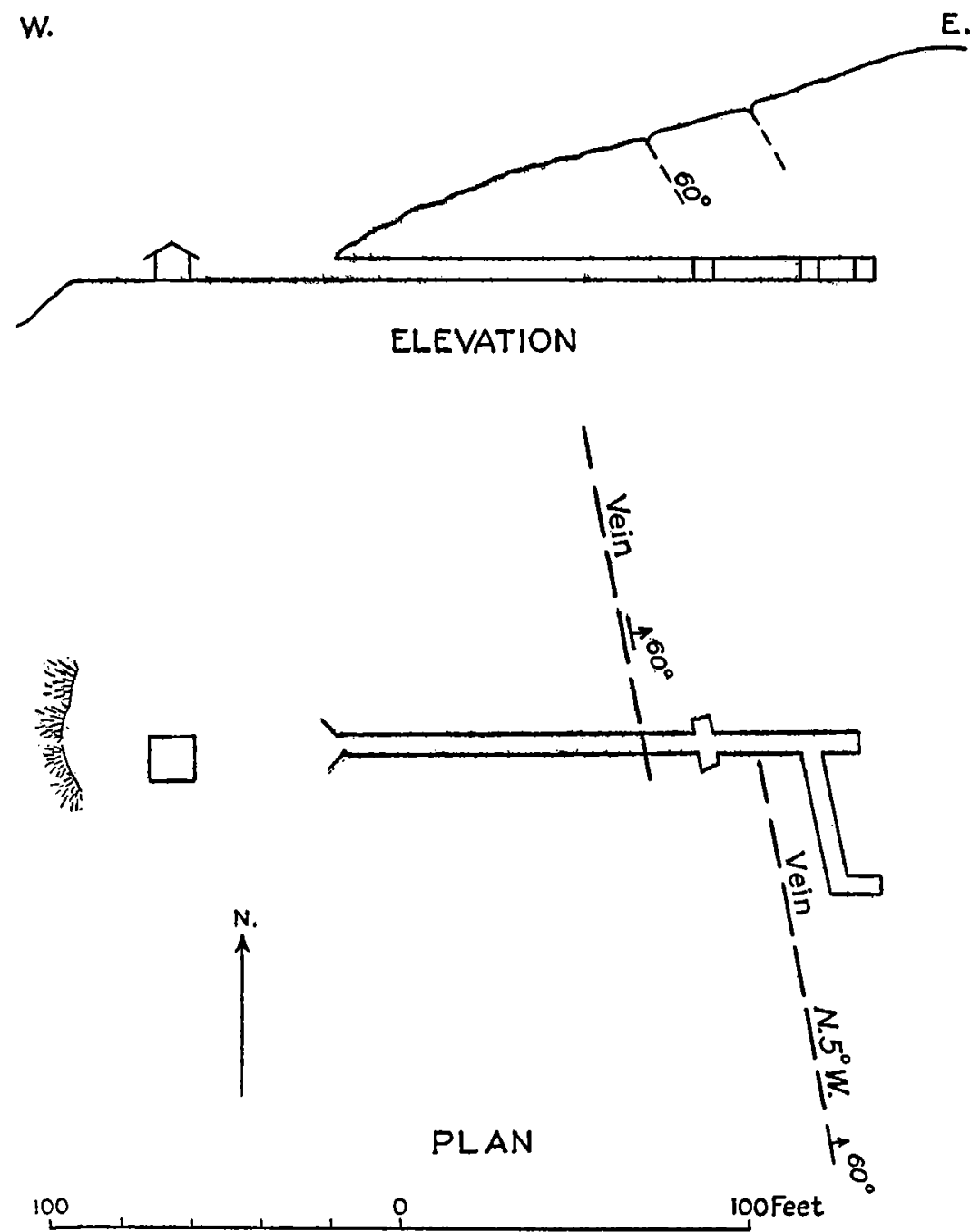

Figdrm 1.-Plan and elevation of auriferous quartz veins and exploratory tunnel on the Wetzler claims on Hurtle Creek.

A tunnel with its portal 90 feet west of the west vein and 50 feet lower than the open cut was driven east 150 feet to intercept the veins. At 10 feet from the face of the tunnel a crosscut 35 feet long was driven to the south, and at the end of that the crosscutting 
to the east was resumed for 8 feet. The relation of the tunnel to the two veins on the surface is shown in figure 1.

A mineralized quartz vein was encountered 10 feet from the face of the main tunnel. This vein is 12 inches thick and is single on the north side of the tunnel. On the south side are two veins 2 feet apart and 10 inches thick, one of which tapers out.

Samples of ore taken from the open cuts, from the tunnel, and from the dump show galena, sphalerite, arsenopyrite, and chalcopyrite or copper pyrite in white quartz. They also contain free gold. Several years ago a small arrastre operated by water power from a little stream crossing the claims was built, but whether any recovery of gold was made is not known to me.

Several other small open cuts on quartz veins in north-south joint planes have been made in the vicinity of the tunnel and at points farther south in the valley, but none of those examined are as large or well mineralized as the two at the tunnel.

The improvements on the property are a cabin and a small tool house and blacksmith shop at the tunnel mouth. If extensive development work is undertaken in the future, some attention will have to be given to the trail, for it is overgrown with alders on the hill slope near the highway and is washed out in a few places. On the whole the ground traversed by the trail is good; the climb out of the Tiekel Valley to the bench is steep, but the footing is firm; and the valley of Hurtle Creek has less soft ground than the character of the topography would suggest, at least in the place selected for the trail.

The Wetzler claims are above timber line and are distant from a source of wood for fuel and mining uses. The nearest timber is around the mouth of Hurtle Creek, on Tonsina Lake, 5 miles away. Lumber for building could probably be obtained more economically from the outside, but for fuel and timbers the local supply will be sufficient for immediate use.

\section{BOULDER CREEK}

Boulder Creek is a short stream about 5 miles long that joins the Tiekel River 1 mile north of the Tiekel Road House and is separated from the heads of the two forks of Hurtle Creek by a rugged mountain ridge. The two chief branches of Boulder Creek head in the divide between Boulder Creek and Stuart Creek which is the next stream on the south, and flow north into the main valley, where they turn to the east. Most of the valley of Boulder Creek is above timber line.

Several discoveries of high-grade gold-bearing quartz made by prospectors on Boulder Creek at various times during a long period 
of years have aroused much interest. Only one of these discoveries, however, has resulted in the production of gold. This was on a property now belonging to $\mathrm{H}$. E. Ellis, for many years a prospector in the Port Valdez and Copper River districts and the discoverer and owner of the Cliff mine. This property originally belonged to Mr. Ellis and Nick Meckem and was called the Eagle mine but is now known commonly as the "Ellis property."

The claims are on the west branch of Boulder Creek, 1 mile north of the saddle between this valley and Mill Creek, a tributary of Stuart Creek, and are reached by a pack trail that starts near the Tiekel Road House and, after climbing a series of switchbacks 1,500 feet or so to the high bench on the south side of the creek, follows a more moderate grade for the remainder of the distance. The whole climb is about 2,900 feet in 4 miles.

The prospect or mine includes several gold-bearing quartz veins in a country rock of slate and graywacke intruded by light-colored porphyry dikes. In places the slate becomes practically a schist. Both the quartz veins and the dikes follow the vertical north-south joints, although some irregular quartz veins are present. All the rocks are faulted and sheared.

A tunnel and several open cuts constitute the development work. Their relation to the principal veins and dikes is shown in figure 2, which is approximately in scale, although the contours are little more than form lines. At $A$ is an open cut or short tunnel on a crushed mass of iron-stained quartz. This yielded high-grade ore, which was treated in an arrastre. A second quartz vein at $B$, a few feet higher than $\mathrm{A}$, is 12 inches thick and strikes $\mathrm{N} .50^{\circ} \mathrm{W}$. The largest vein in view on the property is at $\mathrm{C}$. 'This is a vertical white quartz vein from 2 to 6 feet thick. Parallel to it on the east are three dikes of white porphyry with small flashing crystals of feldspar in a finer groundmass. These dikes range in thickness from 10 inches to 30 feet or more.

The tunnel is 60 feet lower than the outcrop of vein B (see fig. 2) and evidently was driven to intercept it. It is over 100 feet long and nearly straight. At 25 feet from the face a crosscut extends east for 45 feet. Both the crosscut and the main tunnel beyond it are in a complex of quartz veins that do not show on the surface. The mineralized quartz contains free gold, arsenopyrite, and galena, but the two sulphides are not abundant in any of the vein matter in view. So far as the writer knows the vein at $\mathbf{A}$, which is now mined out, was the source of all the gold that has been produced. It was very rich, and from the iron-stained and cavernous appearance of the quartz it must originally have contained more of the sulphide minerals than is seen in any of the other exposures. During the days of 
active mining 5 or 6 men are said to have been employed in mining and milling the ore. The ore was crushed in an arrastre operated by water power from the creek and caught with quicksilver. Besides the ore treated with the arrastre, a shipment reported to be 12 sacks of 100 pounds each was taken to the Cliff mine, on Port Valdez, for milling. The quantity of gold produced by this property is not known to me, but to judge by reports of men who worked on or were familiar with it the output appears to have been between $\$ 10,000$ and $\$ 20,000$.

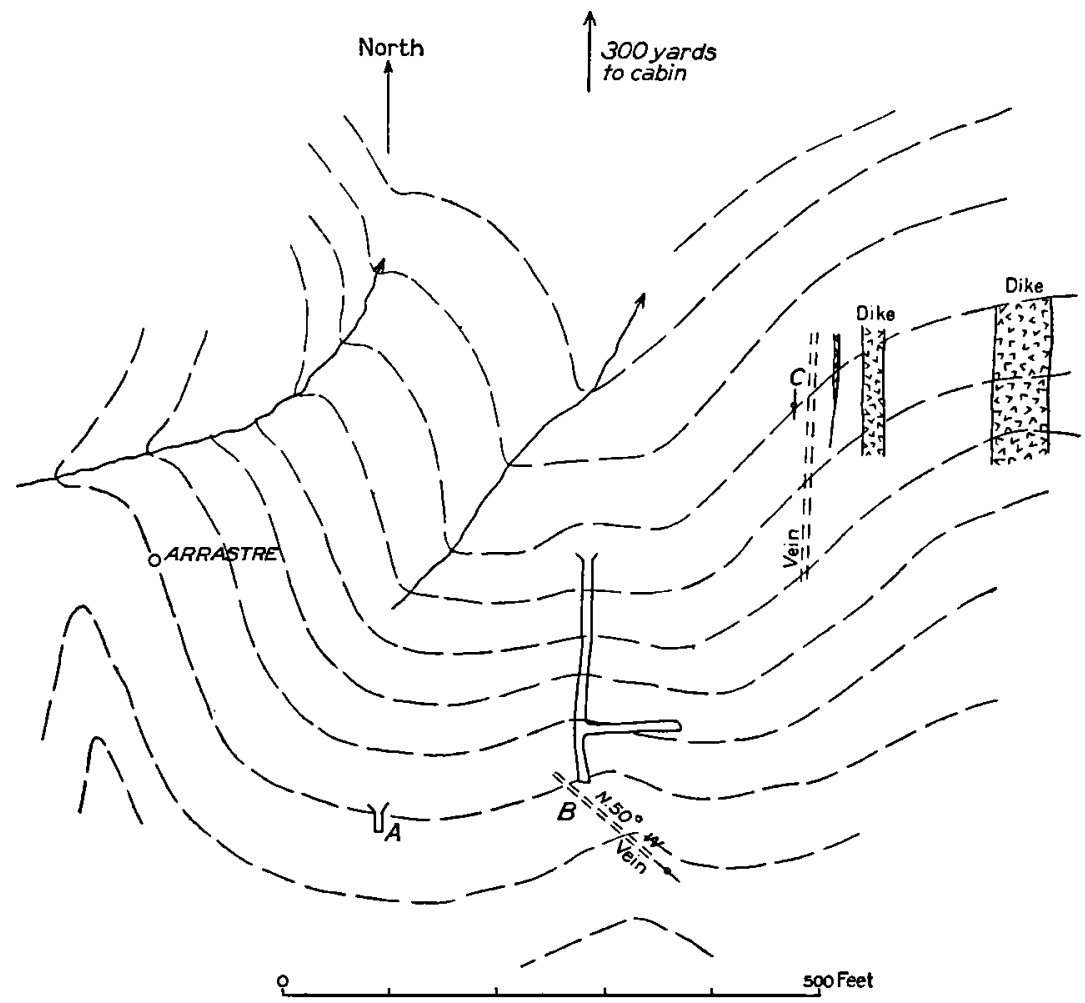

Figurn 2.- Sketch map to show the relation of gold-bearing veins, dikes, and development work at the Ellis claims on Boulder Creek.

No work was in progress on the property in 1932, and except for assessment work none has been done in recent years. The improvements consist of a single unfinished cabin, which, however, could easily be put into usable condition. This property is readily accessible from the highway, so that supplies and equipment may be obtained from Valdez during the summer, when the highway is open. Although the summit at Thompson Pass has not been kept open in winter during recent years, it was used for all traffic with the interior Copper River Basin in the days before the railroad from Cordova 
to Kennecott was built and doubtless could be kept open now if the travel demanded it.

\section{STUART CREEK}

Stuart Creek, known locally as Stuart River, is an eastward-flowing stream slightly more than 10 miles long, which joins the Tsina River near the point where that stream unites with the Tiekel River, not far from mile 47 on the Richardson Highway. It is a swift stream with a strong flow of water, which comes chiefly from small glaciers in the mountains that form the south wall of the valley. Only one small tributary comes in on the north side. This is Mill Creek, slightly over 2 miles long, which heads against Boulder Creek and joins Stuart Creek 7 miles from the mouth. A broad, low pass separates Stuart Creek from the upper valley of the Tonsina River.

A trail for pack horses leads into the upper valley of Stuart Creek. Although this trail climbs 2,000 feet in the first 2 miles, the grades are well chosen, and the ascent is not difficult. After the bench is reached the grades are moderate all the way to Mill Creek, where another steeper climb with no defined trail leads to the cabin on upper Mill Creek. Spruce timber extends from the mouth of Stuart Creek only part way along the trail up the first steep pitch and is succeeded by a dense growth of alder for the next 2 miles. The upper valley is bare of timber, and no more spruce is seen till the divide to the Tonsina Valley is crossed.

Gold-bearing quartz veins were discovered near the head of the Mill Creek Valley in 1923, and a group of claims covering them was staked at that time. The property originally belonged to $\mathbf{M}$. J. Knowles and Oscar Backman. At present it is owned by Mr. Knowles and consists of seven claims together with other ground at the mouth of Stuart Creek. This property is southwest of the property on Boulder Creek already described and about a mile distant. Mill Creek at first flows west and then turns south in a wide curving course to Stuart Creek. The claims are on the mountain slope north of the head of the creek and extend from the base of the slope over the crest of the ridge on the north to the valley of Glacier Creek. The arrangement of claims is shown in figure 3.

The country rock is slate and graywacke of the same character as that on Boulder Creek and like it is cut by white dikes of porphyry, which show distinctly on the bare cliffs. Ice scouring has cleaned out much of the gravel and other debris that probably once covered the valley floor, leaving exposed many bare knobs and low ridges of the country rock, but the smooth slope of the mountain on the north is strewn with a thin veneer of loose angular waste that covers all but a few small outcrops. The system of vertical northsouth joints is well developed in the slate and graywacke, and in 
places these joints furnished a location for the formation of thick lenticular veins of white quartz containing free gold, with a little pyrite and galena but almost no other metallic minerals. Probably oxidation of the surface rocks accounts in part for the scarcity of sulphide minerals on the surface, as iron stains on the quartz indicate the former presence of iron sulphides. In addition to the quartz veins in the north-south joint planes and the veins in fracture planes that do not evidently belong to a well-defined system, irregular bodies of crushed quartz are seen in much sheared and

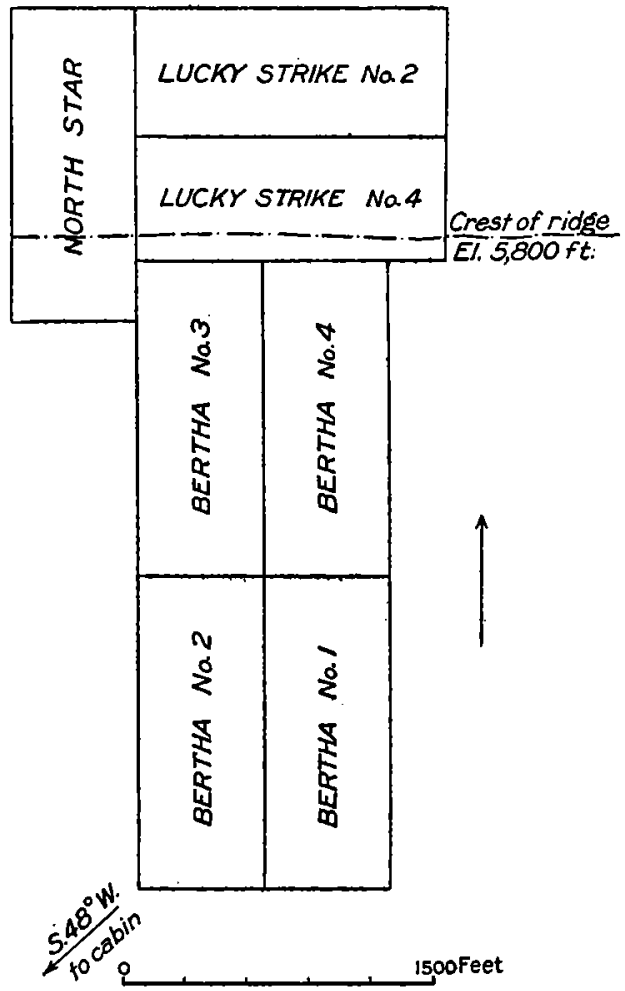

Frodra 3.-Diagram of the Knowles gold-quartz claims on the north side of Mill Creek, a tributary of Stuart Creek.

faulted parts of the bedrock, which appear to be points of intense pressure and movement. These irregular quartz bodies are rudely equidimensional and like the other veins have been sheared and mashed by deforming forces since their deposition.

The dominant veins occupy the north-south joint planes, but veins in other fracture planes and irregular-shaped masses of quartz related to planes of faulting and shearing are also present. The largest quartz vein in view on the property at the time of visit is near the southwest corner of claim Bertha No. 2. (See A, fig. 4.) 
This vein strikes N. $15^{\circ}$ E., dips $85^{\circ}$ E., and ranges from 10 to 14 inches in thickness. It is exposed in a large open cut for about 25 feet horizontally and vertically. Several branches extend into the cleavage of the slate, which here strikes N. $80^{\circ} \mathrm{W}$. and dips $40^{\circ} \mathrm{S}$. Some faulting has taken place along the vein which sheared the quartz parallel to the sides of the vein. The quartz is stained with iron oxide and contains tiny crystals of pyrite and galena. A dike of intrusive diorite, 2 feet thick, lies roughly parallel to the vein 85 feet to the east.

Several other quartz veins at practically this same altitude $(5,000$ feet) are exposed in a distance of 1,000 feet to the east along the south boundary of claims Bertha Nos. 1 and 2. (See B-E, fig. 4.) One which is exposed in an open cut 10 feet square on the boundary line between the two claims (fig. 4, B) is a confusion of quartz lenses and stringers in much crushed country rock along an irregular fault that strikes N. $10^{\circ}$ E. and dips steeply east. The thickest lens strikes east and dips $60^{\circ} \mathrm{S}$., but other veins lie in fractures with different trends.

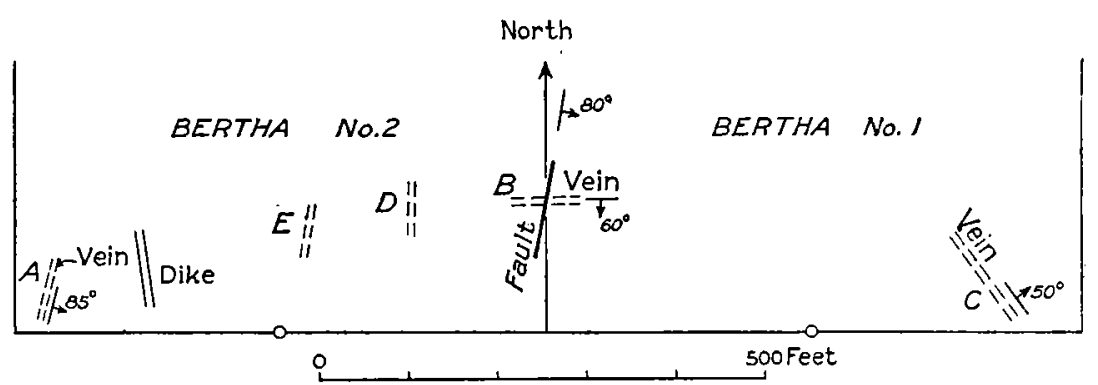

Figdre 4.-Quartz reins on the south ends of claims Bertha Nos. 1 and 2 .

The claims extend north over the ridge between Mill Creek and Glacier Creek, a stream which heads in a cirque basin with precipitous walls and flows west to the Tonsina River. Beginning on the ridge at the west end of the claim Lucky Strike No. 1 and extending east is a succession of quartz veins in vertical north-south joint planes. Four of these of varying thickness up to 12 inches are exposed within a distance of 100 yards in small open cuts. All are crushed and iron-stained, though not cavernous nor crumbly, and contain free gold with a little galena and pyrite. Veins similar to these are exposed on the North Star claim. The south slope of the mountain, covered by claims Bertha Nos. 1, 2, 3, and 4, is strewn with broken rock from which many pieces of gold-bearing quartz were collected. Careful search indicates that no float ore is to be found above a line extending southeastward from the exposures on 
the Lucky Strike No. 1 claim toward the upper valley of Mill Creek. It appears probable from the distribution of the float that several veins may be concealed by the slicle rock.

Development work on the vein deposits has been effected by open cuts. Because of caving of the sides and especially because of the sliding of rock loosened by the movement or melting of snow and ice on mountain slopes in winter and spring, the cuts are difficult to keep open and do not gage the amount of work performed. 'The improvements consist of a cabin and storehouse on Mill Creek near the claims, a cabin and storehouse at the bridge where the old military trail crossed Stuart Creek, and the trail from the lower cabin to the upper Stuart Creek Valley. A small water power is available on Mill Creek in summer. Stuart Creek, however, supplies head and ample water for power the year round, so that electric power is available for mining if further development should justify the construction of a power plant and transmission line. Timber for most mining needs is also available near the mouth of Stuart Creek, although practically all of the Stuart Creek Valley and all of Mill Creek is above timber line. The trail up Stuart Creek provides the best route between the highway and Mill Creek, although the Boulder Creek trail from the Tiekel Road House has been used most by foot travelers, as the southern tributaries of Stuart Creek are swift and filled with boulders and therefore difficult to cross on foot in summer. The construction of one or two small bridges and a relocation of part of the trail in the upper Stuart Creek Valley would obviate the roundabout journey and the crossing of a difficult pass between Boulder and Stuart Creeks.

\section{OTHER PROSPECTS}

Other prospects of lode and placer gold have been discovered within the Tonsina district during the years since the first influx of gold seekers in 1898 , but apparently none of them were receiving any attention in 1932, with the exception of a lode prospect near mile 40 on the Richardson Highway. Lode claims on Quartz and Boulder Creeks, described in $1918,{ }^{17}$ have been abandoned, for little if any work has been done on them in recent years.

The lode prospect at mile 40 on the Richardson Highway was discovered many years ago and has been in the ownership of several different persons, but is now the property of L. C. Townsend and W. H. Holland. More development work has been done here than at any other property in the district. It consists chiefly of two

${ }^{17}$ Moffit, F. H., Gold lodes in the Tiekel district: U. S. Geol. Survey Bull. 662, pp. 177-182, 1918. 
tunnels which pass beneath the highway, having their portals close to it on the south side. The country rock is much-sheared bluishgray crinkly slate cut by quartz veins. The eastern tunnel is driven N. $60^{\circ} \mathrm{E}$. on a quartz vein that ranges in thickness from 3 to 5 feet. The length of this tunnel is not accurately known, for it was partly filled with ice at the time of visit, but evidently is more than 300 feet. The tunnel is connected with the surface by a raise, which is seen 75 feet north of the highway. A second tunnel was driven at the same level 100 feet west of the first on a quartz vein 1 foot thick, striking N. $40^{\circ} \mathrm{E}$. This tunnel is in much-broken slate like that of the longer tunnel and at the time of visit was badly caved. It is about 150 feet long. In addition to the two tunnels several open cuts were also made at various points near the tunnels.

The quartz carries gold and has been looked on for a long time as a promising prospect, but no gold has been produced from it.

The gravel of Quartz Creek and Fall Creek has long been known to contain placer gold and has yielded a small amount. The Quartz Creek placer was discovered in or about 1898, claims were staked, and mining was carried on. Quartz Creek proved a disappointment, however, and was soon abandoned. The ruins of several cabins near the mouth of Bear Creek give testimony of the work done at that time.

The placer gold of Fall Creek was not discovered until some time after that of Quartz Creek. A little mining was in progress on this stream when I visited it in 1916 , but the production at that time was too small to offer much encouragement to miners, and little work has been done there since.

In the early days prospecting for placer gold was carried on on the Mahlo River, as is shown by abandoned workings and equipment. Evidently the search for gold was not successful.

\section{SUGGESTIONS FOR PROSPECTORS}

All the prospecting that has been done in the Tonsina district so far indicates that gold is the valuable metal most likely to be found there. The gold of the quartz veins is accompanied in places by a little galena, sphalerite, and indications of copper, but no one of these minerals has yet been found in quantities that suggest commercial value.

It is believed that the gold-bearing quartz veins are genetically related to the intrusion of the dikes of porphyritic granite and quartz diorite and are younger than the abundant small quartz veins so highly developed in the slate and graywacke. The gold-bearing quartz veins show a decided tendency to occupy the vertical northsouth joint planes; that is, the system of joints which in general trend 
nearly north and dip at very high angles either east or west. Yet the gold-bearing veins are not confined to such joint planes. None of the gold-bearing veins yet discovered have been shown to continue uninterruptedly for more than a few hundred feet. In general they are rudely lenticular, and their horizontal dimensions may be regarded as giving some indication of the vertical extent. It is suggested that the prospector for lode deposits give special attention to veins of this kind, particularly where they are associated with the light-colored dikes.

Undoubtedly the weathering of the gold-bearing quartz veins has freed gold, which has found its way into the stream gravel and morainal deposits. Deposits of placer gold may be found, yet the valleys throughout the district have been so scoured out by ice that the older preglacial concentrations of gravel have probably been entirely removed. It is suggested that if any search for placer gold is undertaken, attention should be directed particularly to places where the present streams are reworking old bench and terrace gravel. The reconcentration of gold sparsely scattered in unconsolidated deposits is the chief reason for the value of many Alaskan gold placers. 


\section{INDEX}

Abstract of report. Bertha claims. See Knowles claims.

Boulder Creek, claims on--.---_---

lode claims on, abandoned

Carboniferous (?) and associated rocks, undifferentiated, age and correlation of - 13-14 undifferentiated, character and distribution of intrusives in bedded rocks of

thickness and structure of - 12-13

Carboniferous time, events of -_-_- 22-23

Chapin, Theodore, quoted____._-_ 11

Cretaceous (?) and associated rocks, age and correlation of - $_{-}$17-18 character and distribution of --- 15-17 intrusives in (........... 18-19 thickness and structure of.-..- 17

Drainage, features of changes in

Eagle mine. See Filis claims. Ellis claims, developments on_-_--_ 30-32 $+$

Fall Creek, placers on-_-_-_--_- 36

Field work___. 3-4

Geologic history

Geologic reconnaissance map of the district_-._- pl. 1 (in pocket)

Geology, general features of Glacial deposits, occurrence and character of _........ 19-21

Glaciation, history of

Glacler Creek, claims in valley of -- $32-35$

Gold, occurrence of

Hurtle Creek, claims on

Intrusives, occurrence and character of, in bedded Carboniferous (?) rocks_-_-_-- 14-15 occurrence and character of, in Cretaceous ( ?) rocks_- 18-19

Joint planes, north-south system of, mineralized quartz veins along.-- 12-13, 36
Page

Knowles claims, developments on_-_ 34-35 geology of

Lucky Strike claims. See Knowles claims.

Mahlo River, prospecting for placer gold on

Mesozoic time, events of

Mill Creek, claims on

Mineral resources__-_- 26-37

Morainal deposits, occurrence and character of

North Star claim. See Knowles claims.

Placers, occurrence of prospecting for 36 36-37

Present investigation.-_-_-_-_-_ $3-4$

Previous work, review of

Prospectors, suggestions for

Quartz Creek, abandoned lode claims on -...- 35

placers on

Quartz veins, occurrence and character of

occurrence of gold in

Quaternary deposits, occurrence and character of

Relief, features of

Richardson Highway, lode prospect at mile 40 on

Routes of travel

Slate-graywacke formation, age and correlation of

character and distribution of -- 15-17 intrusives in

occurrence of gold in.--_-_-_- 26

thickness and structure of

Structure-_-_._-_-_-_-_-_-_--- 21-22

Stuart Creek, claims in valley of $---32-35$

Timber and vegetation_-_-_-_- 8

Tcwnsend \& Holland, lode prospect

of -- -

Trails__._-_._- 7

Wetzler claims, developments on mineralized quartz veins on 


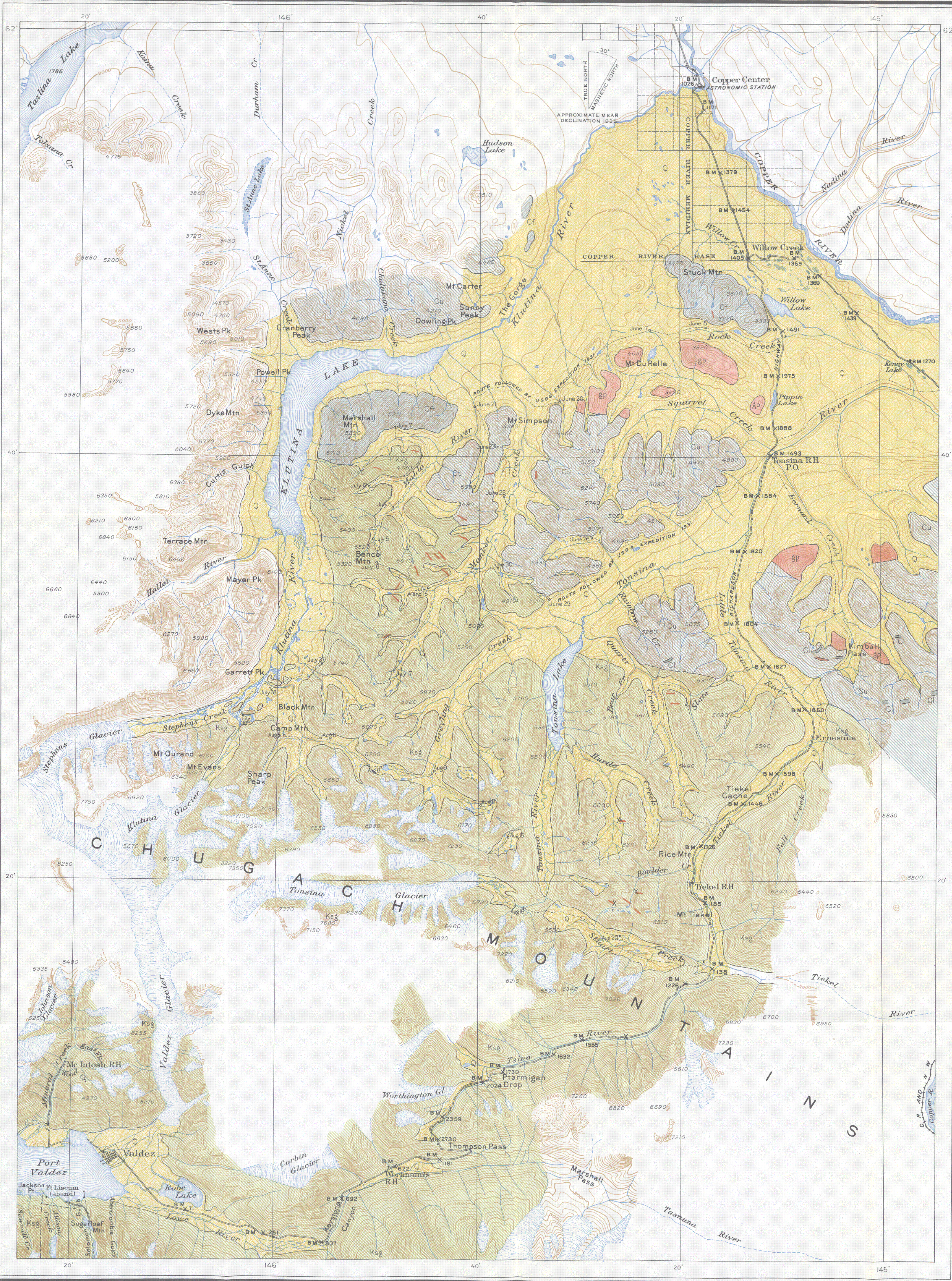

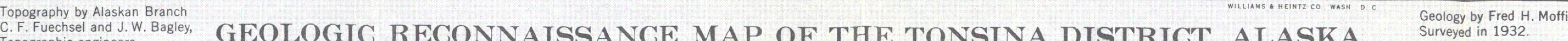
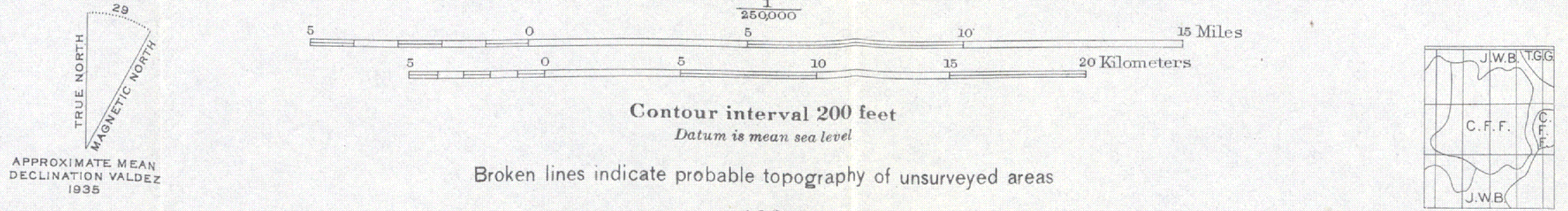
